\title{
DETECTION OF DIFFERENT STAPHYLOCOCCUS AUREUS STRAINS IN BOVINE MILK FROM SUBCLINICAL MASTITIS USING PCR AND ROUTINE TECHNIQUES
}

\author{
Olney Vieira-da-Motta ${ }^{1}$; Márcio Manhães Folly ${ }^{1 *}$; Cássia Camargo Hagen Sakyiama² \\ ${ }^{1}$ Laboratório de Sanidade Animal, ${ }^{2}$ Laboratório de Melhoramento Genético Vegetal. Centro de Ciências e Tecnologias \\ Agropecuárias, Universidade Estadual do Norte Fluminense-UENF, Campos dos Goytacazes, Rio de Janeiro, Brazil.
}

Submitted: June 30, 1999; Returned to authors for corrections: October 20, 1999; Approved: March 07, 2001

\begin{abstract}
Contamination of fresh milk with Staphylococcus aureus was assessed comparatively through routine phenotypic (coagulase tube test and coagulase slide test) and genotypic (PCR) screening of 128 S. aureus strains isolated from 555 milk samples. These samples were collected from 362 cows with subclinical mastitis, hosted in different dairy herds at various locations of the Northern and Northeastern rural areas of the State of Rio de Janeiro, 39.7\% of which were CMT-positive. All S. aureus isolates tested positive for the presence of the coagulase gene by PCR and the isolates could be grouped into four distinct classes according to the size of the PCR product. The strains also yielded variable results when assayed with coagulase test. Taken together, these data indicate the existence of extensive polymorphism at the coagulase gene locus in the genus Staphylococcus and exemplifies the extent of molecular and phenotypic heterogeneity associated with the strains circulating in rural herds.
\end{abstract}

Key words: bovine mastitis, Staphylococcus aureus, coagulase, PCR

\section{INTRODUCTION}

Bacterial infections of the mammary gland result in inflammation of the infected organ, a condition known as mastitis. Mastitis can be either moderate (subclinical) or severe (clinical) in which alterations of both udders and milk are visible to the naked eye. Untreated mastitis is one of the main causes of continuous economical losses in the dairy industry $(8,9,24)$. Staphylococcus aureus infections of the udder generally result in subclinical mastitis. However, infections can progress into clinical manifestation to include systemic signals, particularly at calving and postpartum periods $(14,24)$.

Successful technological advances towards rapid and sensitive methods for the differential diagnosis of microbes resulted in an increasing number of biochemical and enzymatic tests, most of which are based on genotypic analyses. Altogether, these tests can be used to discriminate between otherwise indistinguishible bacteria commonly found in contaminated milk and milk products (13). Although the coagulase tube test is the standard phenotipic routine test used to identify S. aureus in biological samples (5), several groups have implemented the molecular analysis of the coagulase gene as an accurate defined test $(1,11,15)$. More recently, Mathews et al. (17), using arbitrary primers to amplify target genes by PCR, called attention to the risk of possible diagnostic errors in the identification and differentiation of coagulase-negative $S$. aureus through conventional phenotypic assays.

The present study reports results of the incidence of $S$. aureus in bovine milk samples from subclinical mastitis, collected in the North and Northeast regions of the State of Rio de Janeiro, Brazil. The study also reports differences in results using either routine techniques or molecular typing of the coagulase gene (coa) by primer specific PCR.

\section{MATERIALS AND METHODS}

Milk samples were collected from three hundred and sixty two cows, hosted in herds at 64 rural properties in 15 municipalities of the Northern and Northeastern areas in the State of Rio de Janeiro,

\footnotetext{
* Corresponding author. Mailing address: Lab. de Sanidade Animal, Universidade Estadual do Norte Fluminense, Av. Alberto Lamego, 2000, Horto, CEP 28015-620, Campos dos Goytacazes, RJ, Brazil. E-mail: folly@uenf.br
} 
Brazil. The samples were collected in a two-year period (1995 to 1997). Farms, animals and samples were randomly selected. CMT of milk samples was performed using a commercially available test (FATEC, SP, Brazil). CMT-positive samples were transported to the laboratory on ice. All samples were incubated at $37^{\circ} \mathrm{C}$ for 18 hours and then inoculated on selective Chapman (Merck, Germany) agar and 5\% sheep blood agar plates. Hemolysis, morphology, and pigmentation were scored after 24 hours incubation at $37^{\circ} \mathrm{C}$. Growth on Chapman agar was scored after a 48 hours incubation at $37^{\circ} \mathrm{C}$. Colonies yielding Gram-positive cocci were subjected to biochemical tests for catalase, oxidase (DrySlide Oxidase Difco, USA), acetoin production (VP), anaerobic mannitol fermentation (Difco, USA). Coagulase test $(5,16)$ was performed as follows. Two drops of cultures in TSB (Tripticase Soy Broth, Merck, Germany) were added to tubes containing $0.5 \mathrm{ml}$ of citrate rabbit plasma (Bacto Coagulase Plasma, Difco, USA) and clot formation was observed every two hours for a 24 hour period. S. aureus strain ATCC 25923 was used as a positive control and S. schleiferi (isolated by the authors) as a negative control. To investigate production of bound coagulase and protein A, the Bacto Staph Latex Test kit (Difco, USA) was used according to the manufacturer instructions. Production of DNAse was tested in agar DNAse, using $\mathrm{HCl} 1.5 \mathrm{M}$ to visualize halo formation around the colonies.

Molecular typing of the coa gene was performed by the method of Goh et al. (11) modified by Aarestrup et al. (1). Cells from an overnight culture in TSB were washed once ( $4500 \mathrm{rpm}, 5$ minutes) with $500 \mu \mathrm{l}$ of TE buffer (Tris- $\mathrm{HCl} 50 \mathrm{mM} \mathrm{pH} \mathrm{8.3;50} \mathrm{mM}$ EDTA - Sigma; USA), lysed with $15 \mathrm{U \mu l}^{-1}$ Lysostaphin (Sigma, USA) followed by incubation at $37^{\circ} \mathrm{C}$ for 60 minutes. Lysis was completed by adding $1 \mathrm{ml}$ of lysis buffer [ $(0.45 \%$ Igepal, $0.45 \%$ Tween 20, and $60 \mu \mathrm{g}$ Proteinase K $\left(10 \mathrm{mg} \cdot \mathrm{ml}^{-1}\right.$, all from Sigma, USA) in PCR buffer (50 mM KCl, $1.5 \mathrm{mM} \mathrm{MgCl}_{2}, 1 \%$ Triton X$100,1 \% \mathrm{mM}$ Tris- $\mathrm{HCl} \mathrm{pH} 8.3)$ ], then incubated at $56^{\circ} \mathrm{C}$ for 1 hour, followed by 10 minutes at $95^{\circ} \mathrm{C}$ to inactivate Proteinase $\mathrm{K}$.

For amplification of the coa gene the following specific primers were used: 5'ACC ACA AGG TAC TGA ATC AAC G3' (COAG2) and 5'TGC TTT CGA TTG TTC GAT GC3' (COAG3) were used. The primers were purchased from Dr. Charles Lindsey (Escola Paulista de Medicina, Universidade Federal de São Paulo, SP, Brazil). The PCR profile reported by Aarestrup et al. (1) was used. Briefly, $1 \mu \mathrm{l}$ of lysate was added to the PCR mixture containing $1 \mu \mathrm{M}$ of each primer, $200 \mu \mathrm{M}$ of each deoxynucleotide triphosphate (dNTP), 1 U of Taq Polymerase (Gibco, USA) and $3 \mu \mathrm{l}$ of 10X PCR buffer, making a total volume of $40 \mu \mathrm{l}$. The reactions were carried out in a GeneAmp PCR System 9600 (Perkin Elmer Cetus, USA) microprocessor thermal cycler. Profile: 30 seconds at $95^{\circ} \mathrm{C}$, 2 minutes at $55^{\circ} \mathrm{C}$ and 4 minutes at $72^{\circ} \mathrm{C}$, with a total of 40 cycles. PCR products were separated by horizontal electrophoresis on $1.4 \%$ agarose gels (Sigma, USA) in TAE running buffer (1 M Trizma base, $3 \mathrm{M}$ Sodium Acetate, 0.5 M EDTA). DNA fragments were stained with Ethidium Bromide ( $25 \mu \mathrm{g} \mathrm{ml}^{-1}$ Sigma, USA) for 15 minutes and visualized in an UV transiluminator (Sigma, USA).

\section{RESULTS}

A total of 555 milk samples were collected from 362 cows with subclinical mastitis. Nearly $40 \%$ of the animals tested were positive in the CMT. From milk samples of CMT-positive cows, 128 strains of $S$. aureus were isolated. All isolates showed double hemolysis in blood agar, grew on Chapman selective agar, and were positive for DNAse production, mannitol fermentation, catalase and acetoin production (VP), but negative using the oxidase test.

Molecular typing of the coa gene of the 128 isolates, carried out by primer-specific PCR, on Lysostaphin lysates, revealed four fragment sizes (Fig. 1). Fifty-four strains (42\%) were characterized by a distinctive band of approximately 964 bp (lane 4), 29.7\% (38 strains) showed a band of 740 bp (lane 5), $19.5 \%$ (25 strains) a band of $870 \mathrm{bp}$ (lane 3 ) and $8.6 \%$ (11 strains) a 612 bp band (lane 6).

Table 1 presents a comparison of results of the tests used to identify the $S$. aureus strains. While $100 \%$ of the isolates were positive for the presence of the coa gene, the least informative phenotypic test was the coagulase slide test, which exhibited a limited resolving power (2/15 strains). Isolates LSA25 and LSA38 were consistently negative in the tube test while positive in both the slide test and coa gene amplification. All other strains presented positive results in the PCR, tube test and slide test (results not shown). Isolates LSA212 and LSA214 were negative in both the tube and slide tests but positive using PCR.

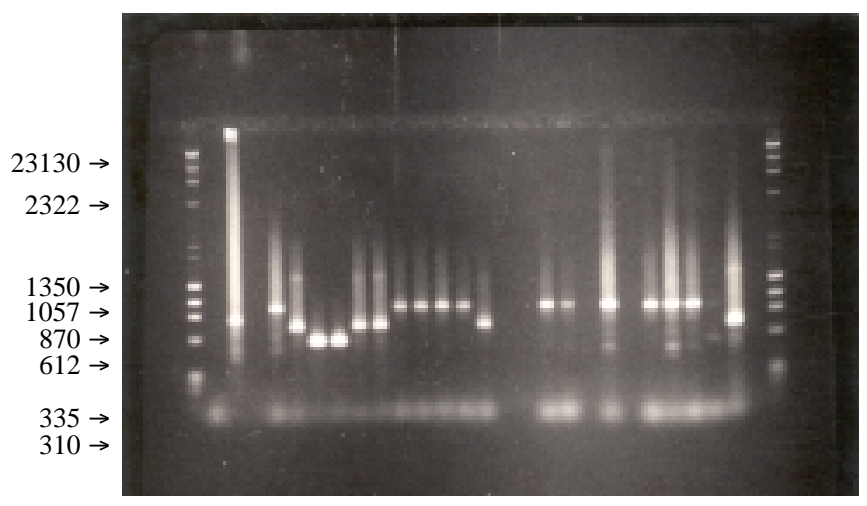

Figure 1. PCR products of selected $S$. aureus strains visualized on agarose gel electrophoresis. Lane 2 negative control (Staphylococcus schleiferi); lane 3 (870 bp), lane 4 (964 bp), lane $5(740 \mathrm{bp})$ and lane $6(612 \mathrm{bp})$ are examples of the fragment sizes seen in $S$. aureus; lane 21 positive control ( $S$. aureus ATCC 25923); lane 22 distilled water control; lane 1 and lane $23 \mathrm{MW}$ marker drigest III ( $\lambda \mathrm{DNA}-H i n d$ III $\phi \mathrm{X}-174$ RF DNA-Hae III Digest). 


\section{DISCUSSION}

Mastitis can be classified as clinical or subclinical. Clinical mastitis is characterized by systemic signals such as anorexia, depression, toxemia, fever, and local signals like hardness of the udder at palpation, edema, increased temperature, hyperemia, and pain. Changes in the mammary secretion can also be seen; usually milk clots can become creamy (pus) and progressive infection can lead to aqueous secretions (20). These symptoms are not observed in subclinical mastitis, but changes in the udder can be detected in the field by qualitative tests (21).

The CMT results for the animals under study showed that $39.7 \%$ of them were positive, indicating that the prevalence of subclinical mastitis in the rural areas studied is higher than previously reported by other authors, in other areas of Brazil. Ribeiro et al. (19), working with 144 mammary quarters of infected cows in Minas Gerais State, found that $15.6 \%$ of them were CMT-positive. Nader Filho et al. (18) found $11.9 \%$ of infected cows in São Paulo State and Ferreiro et al. (10), in Rio Grande do Sul State, 25.5\% CMT-positive. Our results are similar to those found by Harrop et al. (12) and De Freitas and Magalhães (6), in Pernambuco and Rio de Janeiro with $38.15 \%$ and $37.65 \%$ CMT positives, respectively.

Routine bacteriological tests used in the identification of $S$. aureus, like mannitol fermentation, DNAse production, VP, etc., are not enough for definitive characterization $(7,16)$. Nevertheless, coagulase production is still the most traditional test used to identify $S$. aureus (23). The role of coagulase in intramammary infection (IMI) remains uncertain, but it is known

Table 1. Comparison of results for coagulase tests and PCR assay of selected strains of $S$. aureus isolated from mastitic cows.

\begin{tabular}{cccc}
\hline Strain & tube test & $\begin{array}{c}\text { Coagulase test } \\
\text { slide latex test }\end{array}$ & PCR \\
\hline LSA 25 & Negative & Positive & Positive \\
LSA 38 & Negative & Positive & Positive \\
LSA 87 & Positive & Negative & Positive \\
LSA 94 & Positive & Negative & Positive \\
LSA 106 & Positive & Negative & Positive \\
LSA 113 & Positive & Negative & Positive \\
LSA 123 & Positive & Negative & Positive \\
LSA 126 & Positive & Negative & Positive \\
LSA 154 & Positive & Negative & Positive \\
LSA 160 & Positive & Negative & Positive \\
LSA 165 & Positive & Negative & Positive \\
LSA 207 & Positive & Negative & Positive \\
LSA 212 & Negative & Negative & Positive \\
LSA 214 & Negative & Negative & Positive \\
LSA 233 & Positive & Negative & Positive \\
\hline
\end{tabular}

* LSA = Laboratório de Sanidade Animal (Animal Health Laboratory) that most $S$. aureus strains isolated from such infections do, in fact, coagulate bovine plasma. However, the relation between in vitro activity and the actual role of coagulase during IMI has not been established (25). A comparative analysis of 15 strains (Table 1) was thus carried out to re-appraise the discriminatory power of the coagulase tube test, the slide test and PCR. The data showed a marked variation for the slide test. Two out of four strains negative to the tube test $(3.1 \%)$ scored positive by both the slide test (bound coagulase) and PCR. These results suggest that these four strains, although possessing the coa gene, do not express free coagulase in vitro. Similar discrepancies were reported by Schmmitz et al. (22) while analyzing the enterotoxin $\mathrm{C}$ gene in $S$. aureus strains of human origin. They observed that certain $S$. aureus strains expressed undetectable levels of enterotoxin $\mathrm{C}$, while tested positive for the SEC gene as assayed by PCR. As noted by the authors, for epidemiological reasons, toxin genepositive staphylococci may be considered as toxin producers since in vivo toxin production (i.e., during infection) can not be ruled out. Thirteen $(10.1 \%)$ strains were negative by the slide test and positive by PCR, underlying the discrimination power of the latter (Table 1). Baumgartner et al. (2) working with plasmids profiles, found that $11.3 \%$ of the strains were negative using the slide test. Tenover et al. (26) compared traditional and molecular techniques to identify different strains of $S$. aureus from human origin, and that the DNA-based techniques and immunoblotting were the most effective in strain grouping.

Table 2. Product size clones obtained in PCR amplification of the coa gene of $S$. aureus of different sources.

\begin{tabular}{|c|c|c|}
\hline Author/Reference & $\begin{array}{l}\text { PCR product size } \\
\text { class }(\mathrm{bp})\end{array}$ & Source \\
\hline Aarestrup et al. (1995)/ (1) & Not shown & Bovine \\
\hline Goh et al. (1992)/ (11) & $\begin{array}{c}480-730 \\
730 \\
730-980 \\
710-810 \\
355-810 \\
355-610 \\
460-915 \\
500 \\
390-810 \\
760 \\
610 \\
\end{array}$ & Human \\
\hline $\begin{array}{l}\text { Schwarszkopf et al. } \\
(1994) /(23)\end{array}$ & $\begin{array}{l}654 \\
735 \\
816 \\
\end{array}$ & Human \\
\hline $\begin{array}{l}\text { Vieira-da-Motta et al. } \\
\text { (this paper) }\end{array}$ & $\begin{array}{l}612 \\
740 \\
870 \\
964\end{array}$ & Bovine \\
\hline
\end{tabular}


In our hands, PCR amplification of the coa gene, using the same primer sequences previously described as $S$. aureus specific (1), yielded four product size classes (Table 2). Goh et al. (11) and Schwarszkopf et al. (23), using human isolates, reported the occurrence of ten and three PCR product size classes, respectively. Aarestrup et al. (1), working with bovine isolates, further analyzed the extent of the polymorphism associated with the coagulase gene PCR products by restriction enzyme fragment length polymorphisms, and reported fifteen different electrophoretic patterns. In spite of differences in experimental protocols used in these laboratories, it is clear that there is extensive polymorphism associated with the coa gene in circulating strains of either human or bovine origin. Whether the reported PCR product size classes may represent distinct $S$. aureus strains awaits further molecular analysis, particularly at the sequence level. The biological significance of this heterogeneity is also unclear. The question of whether or not such heterogeneity can be manifested as varying coagulase activities also remains. However, it may well be related to differences in virulence/pathogenicity of the strains $(3,11)$. Previous molecular population genetic analysis of $S$. aureus strains recovered from cows (15) or hospitalized patients (4) showed an alarming heterogeneity of circulating strains, even within a given herd or hospital. Regardless a phenotypic association, we believe that the heterogeneity observed for the coa gene has a potential discriminatory power for future epidemiological studies of veterinary and medical importance.

\section{ACKNOWLEDGEMENTS}

Work at the Laboratório de Sanidade Animal is sponsored by FENORTE, Fundação Estadual Norte Fluminense. OVM is a FENORTE fellow. We would like to thank Dr. Enrique MedinaAcosta of the Laboratório de Biotecnologia, UENF, for valuable comments on the manuscript.

\section{RESUMO}

\section{Detecção de diferentes cepas de Staphylococcus aureus de mastite bovina subclínica através da técnica de PCR e técnicas tradicionais}

Quinhentas e cinqüenta e cinco amostras de leite, provenientes de 362 vacas com mastite subclínica em diferentes propriedades rurais do Estado do Rio de Janeiro, Brasil, de 1995 a 1997, foram submetidas ao teste "Califórnia Mastitis Test” (CMT). 39,7\% das amostras foram positivas, das quais foram isoladas 128 cepas de Staphylococcus aureus. Todas as cepas isoladas foram positivas para o gene da coagulase utilizando a técnica de PCR, todavia, resultados de coagulase através das técnicas em tubo e "coagulase slide test" foram variáveis. Após a amplificação do gen de coagulase através da técnica de PCR utilizando iniciadores específicos para o referido gen, fragmentos com diferentes pesos moleculares foram vistos através de análise em gel de agarose, sugerindo a ocorrência de polimorfismo genético. O estudo também sugere a ocorrência de diferentes cepas da bactéria atuando nos rebanhos leiteiros causando mastite bovina.

Palavras-chave: mastite bovina, Staphylococcus aureus, coagulase, PCR

\section{REFERENCES}

1. Aarestrup, F.M.; Dangler, C.A.; Sordillo, L.M. Prevalence of coagulase gene polymorphism in Staphylococcus aureus isolates causing bovine mastitis. Can. J. Vet. Res., 9:124-128, 1995.

2. Baumgartner, A.; Nicolet, J.; Eggimann, M. Plasmid Profiles of Staphylococcus aureus causing bovine mastitis. J. Appl. Bacteriol., 56:159163, 1984.

3. Belkum, A. Van; Eriksen, N.H.R.; Sijmons, M.J.; Leeuwen, V.W.; Van Bergh, M.; Kluytmans, J.; Espersen, F.; Verbrugh, H. Coagulase and protein A polymorphisms do not contribute to persistence of nasal colonization by Staphylococcus aureus. J. Med. Microbiol., 46:222232, 1997.

4. Belkum, A. Van.; Bax, R.; Straaten, P.J.C.; Quint, W.Gv.; Veringa, E. PCR fingerprinting for epidemiological studies of Staphylococcus aureus. J. Microbiol. Methods, 20:235-247, 1994.

5. Davis, B.D.; Dulbecco, R.; Eisen, H.N.; Ginsberg, H.S. Staphylococci. In: Novick, R.P. (ed.), Microbiology. J.B. Lippincott Co., Phyladelphia, 1990, p.539-550.

6. De Freitas, M. Do A.; Magalhães, H. Enterotoxigenicidade de Staphylococcus aureus isolados de vacas com mastite. Rev. Microbiol., 21:315-319, 1990.

7. Devriese, L.A.; Schleifer, K.H.; Adegoke, G.O. Identification of coagulasenegative staphylococci from farm animals. J. Appl. Bacteriol., 58:45-55, 1985.

8. Fox, L.K.; Gershman, M.; Hancock, D.D.; Hutton, C.T. Fomites and reservoirs of Staphylococcus aureus causing intramammary infections as determined by phage typing: the effect of milking time hygiene practices. Cornell Vet., 81:183-193, 1991.

9. Fox, L.K.; Gay, J.M. Contagious Mastitis. In: Anderson, K.L. (Ed): The Veterinary Clinics of North America: Food Animal Practice. Update on bovine mastitis. W.B. Saunders Co., Phyladelphia 9(3): 475-487.

10. Ferreiro, L.; Ferreiro, C.L.R.; Rangel Júnior, J.J. Mastite bovina na Grande Porto Alegre, RS, Brasil. I - Agentes etiológicos isolados durante o período de 1982-1985. Arq. Fac.Vet., UFRGS, 13:81-88, 1985.

11. Goh, S.H.; Byrne, S.K.; Zhang, J.L.; Chow, A.W. Molecular Typing of Staphylococcus aureus on the basis of coagulase gene polymorphism. J. Clin. Microbiol., 30:1642-1645, 1992.

12. Harrop, M.H.V.; Pereira, L.J.G.; Brito, J.R.F. Incidência de mastite bovina na bacia leiteira do agreste meridional de Pernambuco. Pesq. Agrop. Bras. Ser. Vet., 10:65-67, 1975.

13. Jayarao, B.M.; Gillespie, B.E.; Oliver, S.P. Amplification of randomly amplified polymorphic DNA fingerprinting for species identification of bacteria isolated from bovine milk. J. Food Prot., 59(6), 615-620, 1996.

14. Jones, T.C.; Hunt, R.D.; King, N.W. Genital System. In: Jones, T.C.; Hunt, R.D. and King, N.W. (Eds.). Veterinary Pathology. Williams \& Wilkins, Maryland, 1997, p.1149-1221.

15. Kapur, V.; Sischo, W.M.; Greer, R.S.; Whittam, T.S.; Musser, J.M. Molecular population genetic analysis of Staphylococcus aureus recovered from cows. J. Clin. Microbiol., 33:376-380, 1995. 
16. Langlois, B.E.; Parlindungan, A.K.; Harmon, R.J.; Akers, K. Biochemical Characteristics of Staphylococcus species of human and bovine origin. $J$. Food Prot., 53(2):119-126, 1990

17. Mathews, K.R.; Roberson, J.; Gillespie, B.E.; Luther, D.A.; Oliver, S.P. Identification and differentiation of coagulase-negative Staphylococcus aureus by Polymerase Chain Reaction. J. Food Prot., 60(6):686-688, 1997.

18. Nader Filho, A.; Rossi Jr. O.D.; Iturrino, R.P.S. Pesquisa de Staphylococcus aureus enterotoxigênicos em leite de vacas com mastite subclínica. Rev. Microbiol., 19(4):369-373, 1988.

19. Ribeiro, M.T. Caracterização de Staphylococcus isolados de quartos mamários de bovinos inicialmente reagentes a prova do "California Mastitis Test”. Rio de Janeiro, 1991, 62p. (M.S. Thesis. Instituto de Veterinária. UFRRJ).

20. Saran, A. Mastitis Bovina: Enfermidades de la ubre y su control en Israel; Inst. Vet. Kimron. Israel, 1986. 72 p.

21. Schalm, O.W. and Noorlander, D.O. Experiments and observations leading to development of the California Mastitis Test. JAVMA, 130(5):199-207, 1957.
22. Schmitz, F.-J.; Steiert, M.; Hofmann, B.; Verhoef, J.; Hadding, U.; Heinz, H.-P.; Köhrer, K.O. Development of a multiplex-PCR for direct detection of the genes for enterotoxin B and C, and toxic shock syndrome toxin-1 in Staphylococcus aureus isolates J. Med. Microbiol., 47: 335-340, 1998.

23. Schwarszkopf, A.; Karch, H. Genetic Variation in Staphylococcus aureus coagulase genes: potential and limits for use as Epidemiological marker. $J$. Clin. Microbiol., 32(10):2407-2412, 1994.

24. Sordillo, L.M.; Shafer-Weaver, K.; Derosa, D. Symposium: bovine immunology. Immunology of the mammary gland. J. Dairy Sci., 80:18511865, 1997.

25. Sutra, L.; Poutrel, B. Virulence factors involved in the pathogenesis of bovine intrammamary infections due to Staphylococcus aureus. J. Med. Microbiol., 40:79-89, 1994.

26. Tenover, F.C.; Arbeit, R.; Archer, G.; Biddle, J.; Byrne, S.; Goering, R.; Hancock, G.; Herbert, G.A.; Hill, B.; Hollis, R.; Jarvis, W.R.; Kreiswirth, B.; Eisner, W.; Maslow, J.; Mcdougal, L.K.; Miller, J.M.; Mulligan, M.; Pfaller, M.A. Comparison of traditional and molecular methods of typing isolates of S. aureus. J. Clin. Microbiol., 32(2): 407-415, 1994. 